\title{
THE SIGNIFICANCE OF LUNG FUNCTION CHANGES IN ASBESTOSIS
}

\author{
BY \\ ROGER WILLIAMS* AND P. HUGH-JONES \\ From the Department of Medicine, Postgraduate Medical School of London
}

(RECEIVED FOR PUBLICATION DECEMBER 21, 1959)

\begin{abstract}
Asbestos is the name given to a series of minerals composed of fibrous silicates of magnesium and iron which find widespread use in industry. Inhalation of the dust may cause asbestosis, a crippling form of pulmonary fibrosis, which usually does not appear until many years after the initial exposure. There is also an increased incidence of carcinoma of the lung in patients with asbestosis, and Doll (1955) estimated that the risk of lung cancer in asbestos workers was approximately 10 times greater than in the general population.

The diagnosis of asbestosis at present depends on the history of exposure to the dust together with certain physical signs and radiological changes. The most characteristic features of the latter are a " ground-glass" mottling of the lower zones of the lung fields with a shaggy border to the heart. The physical signs are clubbing of the fingers and fine metallic crepitations on auscultation of the lung bases. Unfortunately many cases even with definite physical signs do not show the characteristic radiological changes, and the early diagnosis of the disease may be most difficult. The presence of "asbestosis bodies" in the sputum simply proves that asbestos dust has been inhaled and does not necessarily imply that fibrosis is present.

The purpose of the present work was to relate the changes in lung function in asbestosis to the clinical and radiological signs of the disease and to try and determine the value of lung function tests in assisting with its early diagnosis.
\end{abstract}

\section{Previous Lung Function Studies}

It has been known for some time that the main functional defect in asbestosis is a reduced diffusing capacity of the lungs. In early reports (Roemheld, Kempf, and Wedler, 1940 ; Baldwin, Cournand, and Richards, 1949; Gernex-Rieux, Balgairies, and Claeys, 1954 ; Bastenier, Denolin,

*Present address: Medical Unit, Royal Free Hospital, Gray's Inn Road, London, W.C.1. de Coster, and Englert, 1955) this was inferred from the occurrence of arterial oxygen desaturation on exercise. Other changes noted were marked hyperventilation on exertion, with relatively well-maintained tests of ventilatory capacity. This functional pattern, which was called by Austrian, McClement, Renzetti, Donald, Riley, and Cournand (1951) the syndrome of "alveolarcapillary block," occurs in a whole group of uncommon diseases characterized pathologically by interstitial fibrosis. Wright (1955b) described a series of 57 men with varying degrees of exposure to asbestos dust, who had been studied at the Trudeau Foundation. He found a reduced partial pressure of oxygen in the arterial blood despite normal levels in the alveolar gas, and similarly concluded that the primary lesion was a reduction in diffusing capacity, though there was also a moderate reduction in the inspiratory capacity resulting from the fibrosis which often led to an appreciable reduction in maximum breathing capacity. There was no consistent relation, however, between the functional changes and the radiological appearances. More recently Bader, Bader, and Selikoff (1957) studied 18 patients with asbestosis and measured the diffusing capacity for oxygen by the method of Riley and Cournand in five of them. In only three of these was it significantly reduced.

\section{Subjects STUdied}

Forty patients in all were seen. These were divided into three groups.

Group 1.-This consisted of 21 cases of asbestosis. They had all been seen and certified by the pneumoconiosis medical boards and were receiving disability pensions ranging from 10 to $80 \%$.

Group 2.-This comprised 10 men from the same factory as the patients in the first group. They had been exposed to asbestos dust for vary- 
ing periods of time but had shown no signs of disease and their annual radiograph had been passed as clear.

Group 3.-This consisted of nine men referred for lung function tests in whom the diagnosis of asbestosis had been questioned either because of : inadequate exposure, the absence of the characteristic physical signs, or the presence of atypical radiological changes.

\section{METHODS}

Clinical Assessment.-The patients were routinely admitted to hospital for 36 to 48 hours. The clinical assessment was done independently of the function tests by one observer, and certain of the clinical findings which were later to be compared with the functional results were expressed quantitatively, dyspnoea being graded $0-5$ according to the criteria proposed by Fletcher (1952), and clubbing, crepitations, and wheeze as absent, slight, or marked. A separate study on a later occasion showed that this observer was probably biased towards finding the signs of clubbing and crepitations when the patients were seen in hospital. The laboratory investigations that were performed in nearly all the cases included a blood count, E.S.R. (by the Westergren method), and serum protein and serum bicarbonate estimations. A 24-hour collection of sputum was examined for asbestosis bodies. The electrocardiogram was analysed particularly for evidence of right ventricular preponderance.

Radiological ApPEarances.-It was considered that the only radiological change in asbestosis capable of being graded was the degree of mottling. This was assessed independently by a group of four observers using three standard films (grades 1, 2, and 3) chosen to represent the range of mottling seen in asbestosis. Each zone of the lung field was considered separately and the findings later added together to form a total score (possible range $0 \rightarrow 18$ ). The mean of the readings of the four observers (three physicians and a radiologist at Hammersmith Hospital), who had special experience in the reading of pneumoconiosis films, was taken as the radiological grade. Special note was also made of the presence or absence of bullae which were defined as translucent areas greater than $1 \mathrm{~cm}$. in diameter. Full details of the technique of radiological grading and the effect of observer variability on the readings obtained are given elsewhere (Williams and HughJones, 1960).

Lung Function Tests.-The following tests were carried out, all gas volumes being measured at ambient pressure and room temperature.

(1) Resting Ventilation.-This was measured after the patient had been resting quietly for at least 20 minutes using a vane anemometer which has negligible resistance (Wright, 1955a).
(2) Exercise Ventilation.-The standard exercise $\stackrel{\vec{F}}{\rightarrow}$ test described by Hugh-Jones (1952) was used. The standardized ventilation (S.V.) was preferred to the 흠 exercise ventilation as a measure of the ventilatory $\frac{\bar{s}}{\square}$ cost of exercise, as it is valid even in patients who are $\mathbb{\nabla}$ unable to complete the full five minutes of exercise.

(3) Maximum Breathing Capacity.--This was esti- 2 mated indirectly from the mean of three consistent $\vec{\circ}$

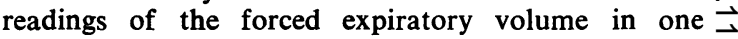
second (F.E.V.1.0) recorded as a tracing using a low- $\vec{\omega}$ resistance spirometer (Bernstein, D'Silva, and Mendel, 1952). The ratio of the F.E.V.1.0 to the vital capacity $\vec{x}$ was calculated (known as the F.E.V.\%). The test $\vec{v}$ was repeated after the patient had inhaled an aerosol iv of $1 \%$ isoprenaline for five minutes in order to detect any labile air-flow obstruction.

(4) Lung Volumes.-These were determined by the $\frac{\text { ㅇ }}{2}$ closed-circuit helium-dilution method (Gilson and Hugh-Jones, 1949), the normal values being predicted $\subseteq$ from the simplified regression formulae derived by Needham, Rogan, and McDonald (1954).

(5) Diffusing Capacity.-This was measured by the $\mathscr{\mathscr { O }}$ single-breath carbon monoxide method using the simplified technique described by Ogilvie, Forster, Blakemore, and Morton (1957). Subsequent calibra- 主 tion of the apparatus suggested a small systematic error. This does not affect the validity of the results as the values for diffusing capacity have been $\frac{\mathcal{}}{\varnothing}$ expressed as a percentage of normal, the normal $\varrho$ values being predicted from a regression on surface $\overrightarrow{\overrightarrow{0}}$ area derived from a group of normal subjects studied 3 using the same technique.

(6) Arterial Oxygen Saturation.-This was measured at rest using the spectrophotometric method in all the patients in whom cyanosis was suspected clinically.으 Changes in oxygen saturation during the standard exercise test were measured using a Waters-Conley ${ }^{-}$ ear oximeter in the majority of patients in Groups 23 and 3.

(7) Inequality of Ventilation, Perfusion, and Ventilation-perfusion Ratio.-This was estimated by the single-breath test devised by West, Fowler, HughJones, and O'Donnell (1957) using a suitable mass spectrometer.

\section{RESULTS}

Group 1.-The main clinical findings are given N in Table I. The average exposure was 14 years, N but there was a wide range (three to 32 years) and two of the cases had only been exposed for three and three and a half years respectively. The degree of exposure is more difficult to evaluate ase there were no satisfactory measurements of dust concentration during this period, but the majorityo of the patients in this group had worked in particularly dusty departments such as the opening and crushing, weaving and sectional departments $\frac{\varrho}{\sigma}$ of the factory before modern methods of dust prevention had been introduced. One patiento 
TABLE I

CLINICAL DATA ON 21 RECOGNIZED CASES OF ASBESTOSIS (GROUP 1)

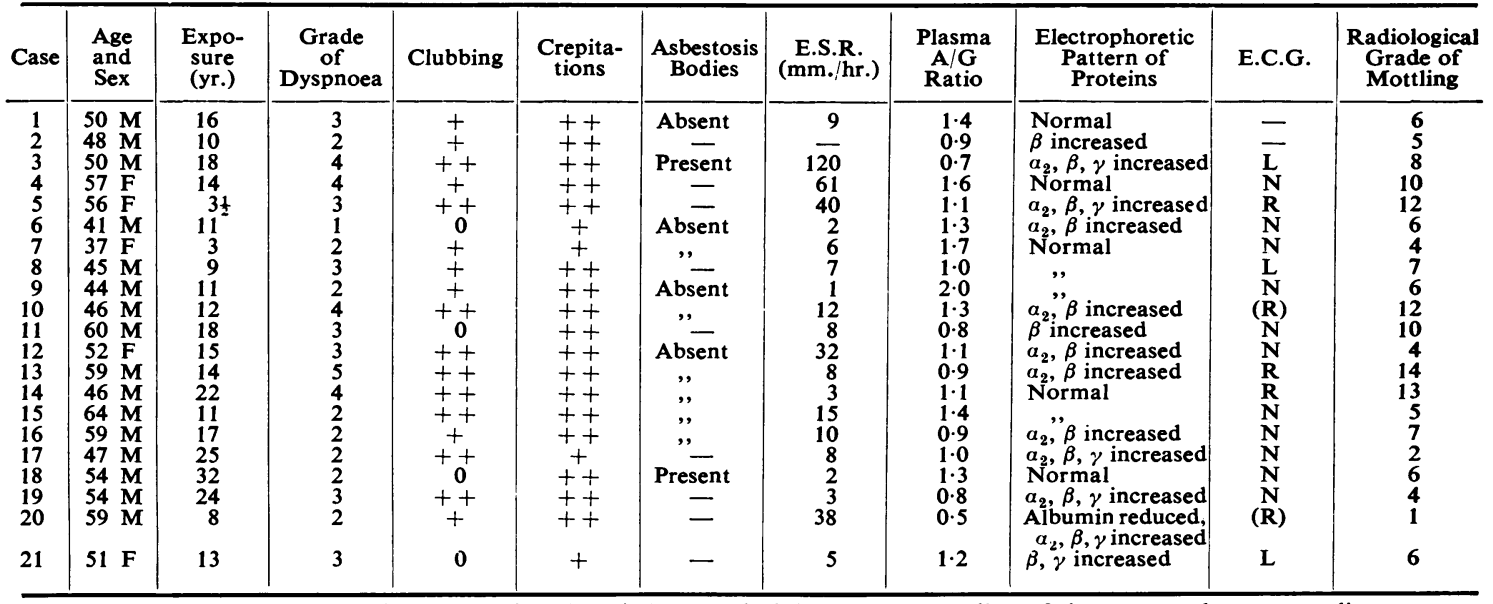

Clubbing and crepitations graded absent $(0)$, slight $(+)$, or marked $(++)$. For grading of dyspnoea and $x$-ray mottling see text. Electrocardiogram: $N=$ Normal, $L=$ left ventricular preponderance, $R=$ right ventricular preponderance. $(R)=$ borderline $R . V . P$.

(Case 19) had never actually worked with asbestos, though, as works carpenter, he had been employed in many of the dusty departments. All except one (Case 6) complained of breathlessness on exertion with serious limitation of their exercise tolerance. Another rather characteristic feature was a distressing paroxysmal cough often precipitated by exertion. Sputum was invariably scanty and mucoid. Asbestosis bodies were present in only two out of the 12 examined. In nine patients it proved impossible to collect an adequate specimen of sputum during their stay in hospital.

The most striking physical signs were clubbing of the fingers and crepitations at the lung bases. Although crepitations were present in all, clubbing was absent in four and marked in nine cases only. Usually these two signs went hand in hand, but there was one patient (Case 16) in whom the degree of clubbing was out of proportion to the auscultatory signs. Wheeze, though present in nine cases, was marked in one patient only (Case 20 ), who also gave a clear history of asthma. The chest expansion was often reduced (mean $1 \frac{1}{2}$ in., range $\frac{3}{4}$ in. to $2 \frac{1}{2}$ in.), but this appeared to bear little relation to the radiological severity of the disease. Arterial puncture in all patients thought clinically to be cyanosed showed that definite hypoxia was present in only two (Case 13 saturation $87.5 \%$, Case 14 saturation $84.5 \%$ ). In these two cases and in one other (Case 18) the serum bicarbonate level was slightly raised $(33,32$, and 34 $\mathrm{mEq} / 1$. respectively, upper limit of normal being taken as $31 \mathrm{mEq} / 1$.
The main findings of interest in the clinical investigations were the changes in E.S.R. and plasma protein fractions. The E.S.R. was increased above $10 \mathrm{~mm}$. $/ \mathrm{hr}$. in eight patients. In only two of these (Case 3 with carcinoma of the lung, Case 5 with rheumatoid arthritis) was there an obvious

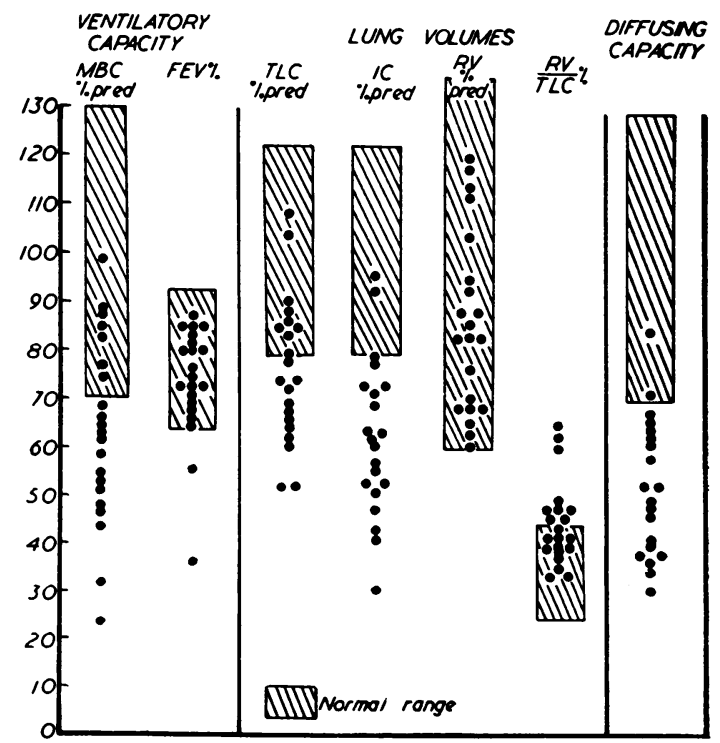

FIG. 1.-The main change in lung function in 21 certified cases of asbestosis (Group 1). The values for maximum breathing capacity (M.B.C.), total lung capacity (T.L.C.), inspiratory capacity (I.C.), residual volume (R.V.), and diffusing capacity ( $D_{c o}$ ) have been expressed as a percentage of the predicted normal. 
explanation other than the asbestosis. Electrophoresis of the serum showed an abnormal pattern in 13 with elevation of the $\alpha_{2}$ and $\beta$ peaks with a less marked increase in $\gamma$ globulin. One case in addition showed a low albumin. The albuminglobulin ratio was reversed in seven of these 13 cases.

LUNG Function StUdiEs.-The results are given in Table II and the main changes illustrated in Fig. 1.

Resting Ventilation.-Six of the 12 cases in which this was measured showed an increase in minute volume, the upper limit of normal with the anemometer technique being $8 \mathrm{l} . / \mathrm{min}$. for males and $51 . / \mathrm{min}$. for females (MacLeish, 1960). In four of these it was due to an increase in respiratory rate with a normal or small tidal volume. In the other two the hyperventilation was the result of an increase in the depth of respiration, the rate remaining normal.

Exercise Ventilation.-Two were unable to perform an exercise test owing to physical deformities. The remainder showed an increased standardized ventilation (S.V.). In those who

TABLE II

RESULTS OF PULMONARY FUNCTION TESTS IN THE THREE GROUPS OF PATIENTS STUDIED

\begin{tabular}{|c|c|c|c|c|c|c|c|c|c|c|c|c|c|}
\hline & \multicolumn{2}{|c|}{$\begin{array}{l}\text { Ind. M.B.C. } \\
\text { (1./min.) }\end{array}$} & \multirow{2}{*}{$\underset{\%}{\text { F.E.V. }}$} & \multirow{2}{*}{$\underset{\text { Rest }}{\text { M.V. }}$} & \multirow{2}{*}{$\begin{array}{c}\text { S.V. } \\
\text { (1./min.) } \\
\begin{array}{c}\text { Exer- } \\
\text { cise }\end{array}\end{array}$} & \multicolumn{4}{|c|}{ Lung Volumes (1.) } & \multirow{2}{*}{ 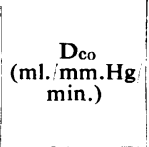 } & \multicolumn{3}{|c|}{$\begin{array}{c}\text { Inequality \% per } 500 \mathrm{ml} . \\
\text { Expired of: }\end{array}$} \\
\hline & \multicolumn{2}{|c|}{ Isoprenaline } & & & & T.L.C. & I.C. & R.V. & $\begin{array}{l}\text { R.V.! } \\
\text { T.L.C. \% }\end{array}$ & & $\begin{array}{c}\text { Ventila- } \\
\text { tion }\end{array}$ & $\begin{array}{l}\text { Per - } \\
\text { fusion }\end{array}$ & $\begin{array}{l}\mathrm{Va} / \mathrm{Qc} \\
\text { Ratio }\end{array}$ \\
\hline $\begin{array}{c}\text { Group } 1 \\
1 \\
2 \\
3 \\
4 \\
5 \\
6 \\
7 \\
8 \\
9 \\
10 \\
11 \\
12 \\
13 \\
14 \\
15 \\
16 \\
17 \\
18 \\
19 \\
20 \\
21 \\
\end{array}$ & $\begin{array}{l}71 \\
95 \\
53 \\
60 \\
38 \\
73 \\
46 \\
87 \\
51 \\
67 \\
87 \\
49 \\
25 \\
36 \\
91 \\
62 \\
88 \\
72 \\
92 \\
58 \\
49\end{array}$ & $\begin{array}{l}71 \\
95 \\
55 \\
62 \\
36 \\
76 \\
48 \\
87 \\
51 \\
66 \\
87 \\
49 \\
27 \\
38 \\
96 \\
64 \\
88 \\
73 \\
94 \\
64 \\
53\end{array}$ & $\begin{array}{l}88 \\
86 \\
75 \\
80 \\
84 \\
71 \\
70 \\
72 \\
86 \\
83 \\
85 \\
80 \\
36 \\
67 \\
72 \\
72 \\
86 \\
66 \\
69 \\
55 \\
76\end{array}$ & $\begin{array}{c}11 \cdot 0 \\
\bar{Z} \\
\overline{7 \cdot 0} \\
\bar{Z} \\
\overline{7 \cdot 0} \\
\overline{7 \cdot 3} \\
\overline{4 \cdot 5} \\
\overline{-} \\
\overline{10 \cdot 0} \\
6 \cdot 8 \\
8.5 \\
10 \cdot 8 \\
7 \cdot 5 \\
7 \cdot 0 \\
14 \cdot 0\end{array}$ & $\begin{array}{l}30 \\
32 \\
55 \\
50 \\
35 \\
42 \\
39 \\
30 \\
43 \\
48 \\
40 \\
49 \\
40 \\
42 \\
39 \\
35 \\
31 \\
34 \\
36 \\
-\end{array}$ & $\begin{array}{l}3.53 \\
4.45 \\
3.26 \\
3.39 \\
2.44 \\
4.63 \\
3.17 \\
5.28 \\
2.78 \\
3.79 \\
4.82 \\
2.92 \\
4.49 \\
3.96 \\
5.90 \\
4.47 \\
4.45 \\
5.49 \\
6.51 \\
4.67 \\
2.97\end{array}$ & $\begin{array}{l}1.70 \\
1.75 \\
1.27 \\
1.47 \\
0.98 \\
2.20 \\
0.98 \\
1.75 \\
0.60 \\
0.92 \\
2.01 \\
1.00 \\
0.94 \\
1.13 \\
1.81 \\
1.51 \\
2.03 \\
1.99 \\
2.11 \\
1.73 \\
1.23\end{array}$ & $\begin{array}{l}1.43 \\
1.56 \\
1.49 \\
1.40 \\
1.17 \\
1.88 \\
1.38 \\
2.05 \\
1.29 \\
2.28 \\
2.03 \\
1.37 \\
2.90 \\
2.45 \\
2.37 \\
2.08 \\
1.54 \\
2.68 \\
2.82 \\
1.69 \\
1.24\end{array}$ & $\begin{array}{l}41 \\
35 \\
46 \\
41 \\
48 \\
41 \\
44 \\
39 \\
46 \\
60 \\
42 \\
47 \\
65 \\
62 \\
40 \\
47 \\
35 \\
49 \\
43 \\
36 \\
42\end{array}$ & $\begin{array}{r}11.6 \\
13.1 \\
11.2 \\
9.9 \\
9.8 \\
16.8 \\
13.3 \\
10.2 \\
13.8 \\
6.4 \\
19.6 \\
10.3 \\
\overline{8.7} \\
9.4 \\
11.9 \\
15.7 \\
18.4 \\
12.8 \\
21.6 \\
17.2\end{array}$ & $\begin{array}{r}17 \cdot 0 \\
7.9 \\
14 \cdot 1 \\
16 \cdot 2 \\
22 \cdot 1 \\
8 \cdot 6 \\
23 \cdot 4 \\
10 \cdot 3 \\
11 \cdot 7 \\
36 \cdot 3 \\
16 \cdot 3 \\
16 \cdot 3 \\
35 \cdot 8 \\
30 \cdot 0 \\
11 \cdot 8 \\
14 \cdot 2 \\
8 \cdot 1 \\
10 \cdot 3 \\
11 \cdot 2 \\
15 \cdot 2 \\
17.6\end{array}$ & $\begin{array}{r}10.1 \\
1.1 \\
5.7 \\
4.3 \\
7.3 \\
-1.3 \\
5.3 \\
8.7 \\
4.4 \\
-5.5 \\
-\overline{2} \cdot 4 \\
-21.9 \\
21.9 \\
17.5 \\
8.0 \\
7.1 \\
4.0 \\
7.9 \\
9.0 \\
6.4 \\
6.9\end{array}$ & $\begin{array}{r}8 \cdot 7 \\
6 \cdot 9 \\
9.9 \\
13 \cdot 1 \\
17 \cdot 1 \\
9 \cdot 1 \\
20 \cdot 5 \\
2.9 \\
7 \cdot 5 \\
39 \cdot 9 \\
-9 \cdot 8 \\
17 \cdot 8 \\
18 \cdot 6 \\
18 \cdot 2 \\
7.1 \\
9 \cdot 8 \\
5 \cdot 1 \\
3 \cdot 6 \\
4 \cdot 3 \\
12.1 \\
12.0\end{array}$ \\
\hline Mean & 64 & 66 & 74 & $8 \cdot 5$ & 40 & $4 \cdot 16$ & $1 \cdot 48$ & $1 \cdot 86$ & 45 & $13 \cdot 1$ & & & \\
\hline $\begin{array}{c}\text { Group } 2 \\
22 \\
23 \\
24 \\
25 \\
26 \\
27 \\
28 \\
29 \\
30 \\
31 \\
\end{array}$ & $\begin{array}{r}95 \\
109 \\
105 \\
82 \\
81 \\
86 \\
73 \\
56 \\
50 \\
54\end{array}$ & $\begin{array}{r}105 \\
117 \\
110 \\
82 \\
88 \\
83 \\
78 \\
66 \\
61 \\
64 \\
\end{array}$ & $\begin{array}{l}64 \\
75 \\
78 \\
74 \\
58 \\
74 \\
62 \\
66 \\
53 \\
77 \\
\end{array}$ & $\begin{array}{r}9.7 \\
10.0 \\
7.7 \\
8.7 \\
10.0 \\
11.0 \\
11.5 \\
9.5 \\
13.3 \\
-\end{array}$ & $\begin{array}{l}31 \\
34 \\
36 \\
28 \\
29 \\
37 \\
35 \\
30 \\
39 \\
37 \\
\end{array}$ & $\begin{array}{l}5.91 \\
5.79 \\
4.91 \\
4.97 \\
5.77 \\
5.09 \\
5.13 \\
5.22 \\
6.02 \\
3.63 \\
\end{array}$ & $\begin{array}{l}1.95 \\
3.39 \\
2.59 \\
1.97 \\
1.81 \\
2.91 \\
2.37 \\
2.49 \\
2.03 \\
1.61\end{array}$ & $\begin{array}{l}2.09 \\
1.83 \\
1.07 \\
1.98 \\
2.42 \\
2.00 \\
1.68 \\
2.57 \\
2.77 \\
1.08\end{array}$ & $\begin{array}{l}35 \\
32 \\
22 \\
40 \\
42 \\
39 \\
33 \\
49 \\
46 \\
30\end{array}$ & $\begin{array}{l}22 \cdot 8 \\
26 \cdot 4 \\
13 \cdot 8 \\
22 \cdot 1 \\
21 \cdot 3 \\
24 \cdot 4 \\
29 \cdot 5 \\
19 \cdot 2 \\
21 \cdot 0 \\
21 \cdot 4\end{array}$ & $\begin{array}{r}5 \cdot 4 \\
2 \cdot 7 \\
6 \cdot 7 \\
10 \cdot 9 \\
6 \cdot 4 \\
6 \cdot 9 \\
7 \cdot 9 \\
8 \cdot 5 \\
13 \cdot 1 \\
-\end{array}$ & $\begin{array}{r}1.6 \\
-0.8 \\
3.8 \\
5.3 \\
3.9 \\
2.5 \\
0.6 \\
5.6 \\
6.6 \\
-\end{array}$ & $\begin{array}{l}4 \cdot 2 \\
3 \cdot 3 \\
4 \cdot 0 \\
6 \cdot 9 \\
3 \cdot 1 \\
5 \cdot 0 \\
7 \cdot 5 \\
3 \cdot 6 \\
9 \cdot 2 \\
-\end{array}$ \\
\hline Mean & 79 & 85 & 68 & $10 \cdot 2$ & 34 & $5 \cdot 24$ & $2 \cdot 31$ & 1.95 & 37 & $22 \cdot 2$ & & & \\
\hline $\begin{array}{c}\text { Group } 3 \\
32 \\
33 \\
34 \\
35 \\
36 \\
37 \\
38 \\
39 \\
40\end{array}$ & $\begin{array}{l}58 \\
75 \\
39 \\
63 \\
72 \\
69 \\
91 \\
84 \\
35\end{array}$ & $\begin{array}{l}60 \\
76 \\
43 \\
68 \\
67 \\
71 \\
94 \\
90 \\
49\end{array}$ & $\begin{array}{l}86 \\
61 \\
46 \\
68 \\
82 \\
73 \\
81 \\
74 \\
46 \\
\end{array}$ & 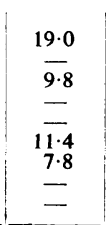 & $\begin{array}{l}78 \\
46 \\
59 \\
45 \\
\\
40 \\
47 \\
42\end{array}$ & $\begin{array}{l}4 \cdot 16 \\
5 \cdot 13 \\
5 \cdot 51 \\
4 \cdot 48 \\
4 \cdot 32 \\
4 \cdot 30 \\
4 \cdot 70 \\
5 \cdot 43 \\
5 \cdot 18\end{array}$ & $\begin{array}{l}0.90 \\
2.21 \\
1.65 \\
1.51 \\
1.31 \\
1.87 \\
1.77 \\
1.59 \\
1.71\end{array}$ & $\begin{array}{l}2.24 \\
1.92 \\
3.64 \\
1.95 \\
2.13 \\
1.43 \\
1.43 \\
2.56 \\
2.71\end{array}$ & $\begin{array}{l}54 \\
37 \\
66 \\
44 \\
49 \\
33 \\
30 \\
47 \\
52\end{array}$ & $\begin{array}{r}9 \cdot 0 \\
12 \cdot 4 \\
14 \cdot 4 \\
15.7 \\
18 \cdot 0 \\
12 \cdot 1 \\
15 \cdot 2 \\
12 \cdot 6 \\
18 \cdot 8\end{array}$ & $\begin{array}{r}19 \cdot 1 \\
15.4 \\
11.9 \\
14 \cdot 2 \\
20 \cdot 5 \\
\overline{8.0} \\
13.0 \\
-\end{array}$ & $\begin{array}{r}14 \cdot 8 \\
12 \cdot 0 \\
0 \cdot 3 \\
9 \cdot 1 \\
15 \cdot 0 \\
-4 \cdot 0 \\
8 \cdot 0 \\
-\end{array}$ & $\begin{array}{r}7.2 \\
7.6 \\
11.8 \\
7.2 \\
10.0 \\
\overline{5.5} \\
9.0 \\
-\end{array}$ \\
\hline Mean & 65 & 69 & 69 & $12 \cdot 0$ & 51 & $4 \cdot 80$ & $1 \cdot 61$ & $2 \cdot 22$ & 46 & $14 \cdot 2$ & & & \\
\hline
\end{tabular}

M.B.C. = maximum breathing capacity, F.E.V. $\%=$ forced expiratory volume $(1 \mathrm{sec})$ as $\%$ of vital capacity, M.V.=minute volume, S.V. $=$ standardized ventilation, T.L.C. = total lung capacity, I.C. = inspiratory capacity, R.V. = residual volume, Dco=diffusing capacity for carbon 8 monoxide, $\mathrm{Va} / \mathrm{Qc}=$ ventilation-perfusion ratio. 
completed the full five minutes of exercise the S.V. was almost identical with the exercise ventilation (E.V.). This would be expected as they had attained a steady state of exercise. In the four who were unable to complete the full period of exercise, the S.V. was greater than the E.V. In two of these (Cases 4 and 7) it is likely that they could have completed the exercise had they been prepared to tolerate the feeling of dyspnoea as the ventilation achieved during exercise had not reached the maximum of which they were capable. In the other two (Cases 5 and 13) the S.V. was greater than their maximum ventilatory capacity and represented a ventilatory debt which continued to increase as long as exercise was continued and which was repaid during recovery.

MaXimum Breathing Capacity.- It can be seen from Fig. 1 that this was reduced in many of the patients, but in only five was it reduced to below $50 \%$ of normal. The mean indirect M.B.C. was $641 . / \mathrm{min}$., which is equivalent to $63 \%$ of that expected in a similar group of normal subjects. In the majority there was little or no response to isoprenaline inhalation, two cases only showing an increase in their M.B.C. of $51 . / \mathrm{min}$. or more. One of these was the patient with a history of asthma and marked clinical wheeze on examination.

The F.E.V.\% was reduced in the patient with asthma and in one other (Case 13). This latter was of considerable interest, for he also had the lowest M.B.C. of the group, and was the only patient who appeared to have a significant degree of complicating emphysema. He died a few months later, and at necropsy was seen to have widespread centrilobular emphysema.

LUNG VOLUMES.-The most striking change was the reduction in inspiratory capacity. As a result, both vital capacity and total lung capacity (T.L.C.) were reduced. The residual volume remained normal, and the ratio R.V./T.L.C.\% was increased-simply as a result of the reduction in T.L.C.

Diffusing Capacity.-This was reduced in all except two cases. One of these was the patient previously referred to with asthma. The other, whose diffusing capacity was right at the lower limit of the normal range, had minimal clinical and radiological signs of the disease.

Ventilation-PERfusion RATIO INEQUALITY.Five patients had ventilation, blood flow, and ventilation-perfusion inequalities within normal limits. The other 15 (one was not tested) showed abnormalities of one or other function. One had an isolated abnormality of ventilation-perfusion ratio. The remaining 14 can be divided into two groups :

(a) The larger group consisted of 12 patients in whom the ventilation blood flow relationship fell into a remarkably constant pattern, consisting of abnormal unevenness of ventilation in association with an even blood flow. This led to the ventilation-perfusion ratio inequality being of the same order as the ventilatory inequality.

(b) Two patients (Cases 13 and 14) had gross inequality of blood flow in addition to gross inequality of ventilation. The ventilationperfusion ratio inequality in these cases was the resultant of the two disordered functions of unequal ventilation and perfusion and did not bear the same close relation to unevenness of ventilation as in the first group. It is of interest that these were the only two in the group who were desaturated at rest.

In summary, the functional changes seen in this group of 21 patients who were thought to have definite clinical and radiological evidence of asbestosis were remarkably constant and consisted of: a lowered overall diffusing capacity of the lungs; a reduced inspiratory capacity; hyperventilation on exercise and a lack of evidence of air flow obstruction as shown by a normal F.E.V.\% unless the disease was complicated, as in two cases, by asthma or emphysema.

Group 2.-The changes in lung function in this group are best considered in relation to the clinical and radiological findings. Although the average exposure in this group was 14 years, the same as in Group 1, the exposure was not comparable as these men had been employed to a much greater extent in less dusty departments, e.g., Case 26 had spent most of his time working in the laboratory testing various compositions of asbestos. In Table III the cases have been arranged according to the changes found in their diffusing capacity.

There were two patients with a normal diffusing capacity. Their radiographs were normal and they had no symptoms or signs. This was despite the fact that one of them had been working with asbestos for 23 years though he remarked that he had always been particularly conscientious about wearing a mask.

There were four patients with a reduced diffusing capacity. Three of these had normal radiographs and only one suggestive signs of asbestosis with the combination of slight clubbing of the fingers and crepitations at the bases. The patient (Case 24) with the most marked reduction 
in diffusing capacity to $47 \%$ of normal had no symptoms or signs but did appear to us to show some radiological changes. The last three cases also showed significant desaturation on exercise. One case only showed a reduced inspiratory capacity.

The remaining four patients had diffusing capacities at the lower limit of the normal range. Three showed minimal radiological changes according to the grading of the independent observers though elsewhere their radiographs had been passed as normal. One had slight clubbing. Other changes in lung function in these cases were a reduced inspiratory capacity in three and abnormal inequality of ventilation in two. These were the only two in this group with abnormal ventilation-perfusion relationships. Blood flow inequality remained within normal limits in both and consequently the ventilationperfusion ratio inequality was of the same order as the ventilatory inequality.
It is of interest that six of the eight patients who had functional evidence of asbestosis also showed similar though less marked changes in their plasma protein fractions to those described in the first

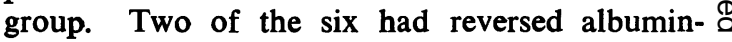
globulin ratios and one an unexplained elevation कै of E.S.R.

The changes in ventilatory capacity in this group bore no relation to the changes in diffusing capacity or radiological appearances. Although $ᄋ$ the mean M.B.C. was higher than that found in $\vec{x}$ Group 1, when this is corrected for age and the $\vec{C}$ values expressed as percentages of predicted iv normal, the reduction in M.B.C. is very similar in $\overrightarrow{-}$ the two groups $(66 \%$ of normal in Group 2 as $\underset{\bullet}{0}$ compared with $64 \%$ in Group 1). The patients 은 in the present group, however, had much more -

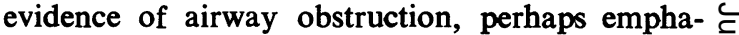
sizing that Group 1 (certified asbestosis) had remarkably little. Eight of the 10 cases showed $\vec{\theta}$ an increase of $51 . / \mathrm{min}$. or more in their M.B.C.

TABLE III

RELATION BETWEEN CLINICAL FINDINGS AND CHANGES IN DIFFUSING CAPACITY IN GROUP 2 CASES

\begin{tabular}{|c|c|c|c|c|c|c|c|c|}
\hline Case & $\begin{array}{l}\text { Ag } \\
\text { and }\end{array}$ & ge & $\begin{array}{c}\text { Exposure } \\
\text { (yr.) }\end{array}$ & Signs & $\begin{array}{c}\text { Grade of } \\
\text { Dyspnoea }\end{array}$ & $\begin{array}{l}\text { Electrophoretic } \\
\text { Pattern }\end{array}$ & Radiograph & $\begin{array}{l}\text { Diffusing Capacity } \\
\text { (\% of Normal) }\end{array}$ \\
\hline $\begin{array}{l}28 \\
23\end{array}$ & $\begin{array}{l}48 \\
40\end{array}$ & $\begin{array}{l}\mathbf{M} \\
\mathbf{M}\end{array}$ & $\begin{array}{l}23 \\
14\end{array}$ & $\begin{array}{c}\text { None } \\
\text {, }\end{array}$ & $\begin{array}{l}0 \\
0\end{array}$ & $\begin{array}{c}\text { Normal } \\
,,\end{array}$ & $\begin{array}{c}\text { Normal } \\
,,\end{array}$ & $\left.\begin{array}{r}100 \\
85\end{array}\right\}$ Normal \\
\hline $\begin{array}{l}30 \\
31 \\
25 \\
22\end{array}$ & $\begin{array}{l}53 \\
43 \\
44 \\
45\end{array}$ & $\begin{array}{l}\mathbf{M} \\
\mathbf{M} \\
\mathbf{M} \\
\mathbf{M}\end{array}$ & $\begin{array}{l}17 \\
14 \\
14 \\
16\end{array}$ & $\begin{array}{c}\text { Clubbing } \\
\text { Crepitations } \\
\text {,, } \\
\text {,, }\end{array}$ & $\begin{array}{l}3 \\
1 \\
1 \\
0\end{array}$ & $\begin{array}{l}\text { Normal } \\
\beta \text { increased } \\
\alpha_{2}, \beta \text { increased } \\
\beta \text { increased }\end{array}$ & 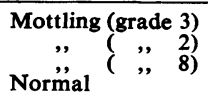 & $\left.\begin{array}{l}79 \\
79 \\
75 \\
74\end{array}\right)$ ? Reduced \\
\hline $\begin{array}{l}26 \\
27 \\
29 \\
24\end{array}$ & $\begin{array}{l}41 \\
52 \\
48 \\
43\end{array}$ & $\begin{array}{l}\mathbf{M} \\
\mathbf{M} \\
\mathbf{M} \\
\mathbf{M}\end{array}$ & $\begin{array}{l}21 \\
10 \\
15 \\
11\end{array}$ & $\begin{array}{l}\text { Crepitations } \\
\text { Clubbing and crepitations } \\
\text { None }\end{array}$ & $\begin{array}{l}0 \\
1 \\
1 \\
0\end{array}$ & $\begin{array}{l}\beta, \gamma \text { increased } \\
\beta, \gamma \text { increased } \\
\text { Normal } \\
\alpha_{2}, \beta \text { increased }\end{array}$ & $\begin{array}{l}\text { Normal } \\
\quad,, \\
\text { Mottling (grade 5) }\end{array}$ & $\left.\begin{array}{r}73 \\
* 72 \\
* 69 \\
* 47\end{array}\right)$ Reduced \\
\hline
\end{tabular}

* These patients showed arterial oxygen desaturation on exercise.

TABLE IV

REASON FOR REFERRAL AND OTHER CLINICAL DATA ON NINE CASES WITH QUESTIONABLE ASBESTOSIS (GROUP 3)

\begin{tabular}{|c|c|c|c|c|c|c|c|c|c|c|c|}
\hline Case & $\begin{array}{l}\text { Age } \\
\text { and } \\
\text { Sex }\end{array}$ & Reason for Referral & $\begin{array}{l}\text { Expo- } \\
\text { sure } \\
\text { (yr.) }\end{array}$ & $\begin{array}{c}\text { Grade } \\
\text { of } \\
\text { Dyspnoea }\end{array}$ & $\begin{array}{l}\text { Club- } \\
\text { bing }\end{array}$ & $\begin{array}{c}\text { Crepita- } \\
\text { tions }\end{array}$ & $\begin{array}{l}\text { Asbes- } \\
\text { tosis } \\
\text { Bodies }\end{array}$ & $\underset{(\mathrm{mm} . / \mathrm{hr} .)}{\text { E.S.R. }}$ & $\begin{array}{c}\text { Plasma } \\
\text { A/G } \\
\text { Ratio }\end{array}$ & $\begin{array}{l}\text { Electrophoretic } \\
\text { Pattern of } \\
\text { Proteins }\end{array}$ & $\begin{array}{l}\text { Radiological } \\
\text { Grade of } \\
\text { Mottling }\end{array}$ \\
\hline 32 & $\begin{array}{l}55 \mathrm{M} \\
45 \mathrm{M}\end{array}$ & $\begin{array}{l}\text { Atypical radiological } \\
\text { appearances, } \\
\text { unusual exposure } \\
\text { Medico-legal assess- }\end{array}$ & 16 & 4 & & & Absent & 13 & $1 \cdot 0$ & & 4 \\
\hline 34 & $52 \mathrm{M}$ & $\begin{array}{c}\text { ment } \\
\text { Mitral stenosis, cys- }\end{array}$ & 12 & 2 & ++ & ++ & - & 6 & $1 \cdot 6$ & Normal & 11 \\
\hline $\begin{array}{l}35 \\
36\end{array}$ & $\begin{array}{l}36 M \\
45 M\end{array}$ & $\begin{array}{l}\text { tic lung } \\
\text { Normal radiograph } \\
\text { Carcinoma lung, }\end{array}$ & $\begin{array}{l}21 \\
17\end{array}$ & $\mathbf{5}$ & $\begin{array}{l}++ \\
++\end{array}$ & $\begin{array}{c}++ \\
+\end{array}$ & $\begin{array}{l}\text { Absent } \\
\text { Present }\end{array}$ & $\begin{array}{r}30 \\
0\end{array}$ & $\begin{array}{l}0 \cdot 7 \\
1 \cdot 3\end{array}$ & $\begin{array}{l}\gamma \text { increased }++ \\
\alpha_{2}, \beta \text { increased }\end{array}$ & $\begin{array}{l}9 \\
1\end{array}$ \\
\hline $\begin{array}{l}37 \\
38\end{array}$ & $\begin{array}{l}63 \mathrm{M} \\
39 \mathrm{M}\end{array}$ & $\begin{array}{l}\text { ? attributable } \\
\text { ? Carcinoma lung } \\
\text { No physical signs, }\end{array}$ & $\begin{array}{r}2 \\
19\end{array}$ & $\begin{array}{l}2 \\
3\end{array}$ & $\begin{array}{c}0 \\
++\end{array}$ & + & Absent & $\begin{array}{l}66 \\
44\end{array}$ & $\begin{array}{l}0.7 \\
0.8\end{array}$ & $\begin{array}{l}\alpha_{2}, \beta, \gamma \text { increased } \\
\alpha_{2}, \beta \text { increased }\end{array}$ & $\begin{array}{r}2 \\
12\end{array}$ \\
\hline 39 & $47 \mathrm{M}$ & $\begin{array}{l}\text { normal radiograph } \\
\text { Ascites due to meso- } \\
\text { thelioma of peri- } \\
\text { toneum,? attribut- }\end{array}$ & 22 & 3 & $\mathbf{0}$ & 0 & , & 6 & $1 \cdot 0$ & $\alpha_{2}, \beta$ increased & 4 \\
\hline 40 & $65 M$ & $\begin{array}{cc}\text { able } \\
\text { Chronic bronchitis }\end{array}$ & $\begin{array}{r}21 \\
4\end{array}$ & $\begin{array}{l}1 \\
2\end{array}$ & $\begin{array}{r}0 \\
+\end{array}$ & $\begin{array}{l}+ \\
+\end{array}$ & $\begin{array}{l}\text { Present } \\
\text { Absent }\end{array}$ & $\begin{array}{l}45 \\
11\end{array}$ & $\begin{array}{l}0.5 \\
1.4\end{array}$ & $\begin{array}{c}\text { Albumin reduced, } \\
\alpha_{2}, \beta \text { increased } \\
\beta \text { increased }\end{array}$ & - \\
\hline
\end{tabular}


after inhalation of isoprenaline and the mean F.E.V.\% was $68 \%$ (cf. $74 \%$ in Group 1). It seems likely that the disability in Case 30 , who was the only patient in this group who admitted to a significant limitation of his exercise tolerance, was related more to airway obstruction than to a diffusion defect as he had a low F.E.V.\% and showed a good response to antispasmodics.

Group 3.-The main clinical findings together with the reason for referral are shown in Table IV.

These were difficult patients to evaluate, as might be expected. But in six (Cases 32, 33, 35, 37,38 , and 40 ) it seemed possible to arrive at a fairly firm conclusion since they showed the functional pattern of an interstitial fibrosis: a reduced diffusing capacity and relatively wellmaintained ventilatory capacity. Exercise oximetry was performed in four, three showed marked desaturation (Cases 31, 37, and 40). In two of these six cases (Nos. 33 and 40) there was also evidence of some degree of airway obstruction. Many of these patients were of considerable interest, and two are illustrated in more detail in Figs. 2 and 3. Case 33 had one of the more bizarre presentations of asbestosis, his first complaint being that he was unable to play cards owing to the clubbing of his fingers.

In the other three patients it was impossible to provide a definite answer. Case 36 had been exposed to asbestos for two years only from 1936-38 but during this time developed breathlessness and wheezing which persisted despite leaving the industry. Radiological changes over the years were minimal until 1958 when he developed a carcinoma of the lung and was treated with radiotherapy, the problem then being whether this was attributable to asbestosis. Although the diffusing capacity was reduced it might equally have been caused by post-radiation fibrosis. In Case 39 some of the reduction in diffusing capacity might have been due to a reduction in lung volume consequent on the high diaphragm and ascites. The problem was complicated in Case 34 by the presence of mitral stenosis and incompetence. He also had functional evidence of emphysema with a low M.B.C., reduced F.E.V.\%, and considerably increased residual volume ( $157 \%$ of predicted normal).

\section{Correlation Between Clinical, Radiological, and Functional Changes}

The findings in the first 38 patients have been analysed statistically. In the correlations with



(a)

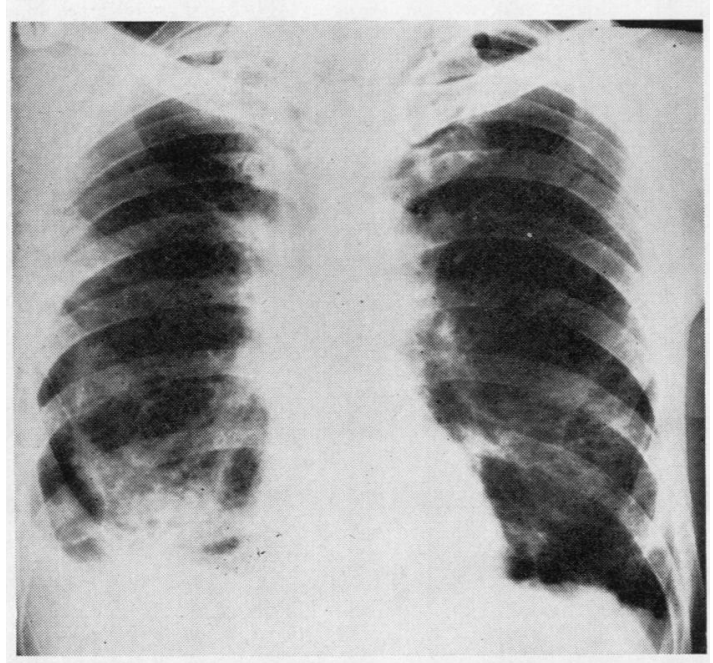

(b)

FIG. 2.-The functional changes (a) in a patient (Case 32) with unusual radiological appearances; $(b)$ the radiograph showing large bullae and coarse fibrotic scarring at the right base. Exposure was for 16 years when the patient was covering electric welding rods with asbestos yarn. 


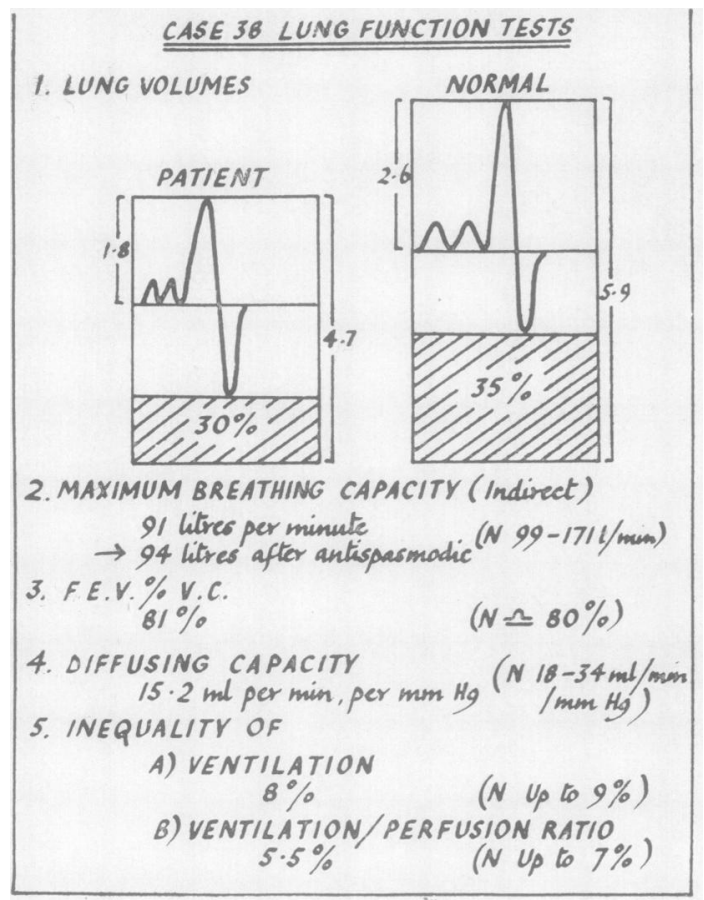

(a)

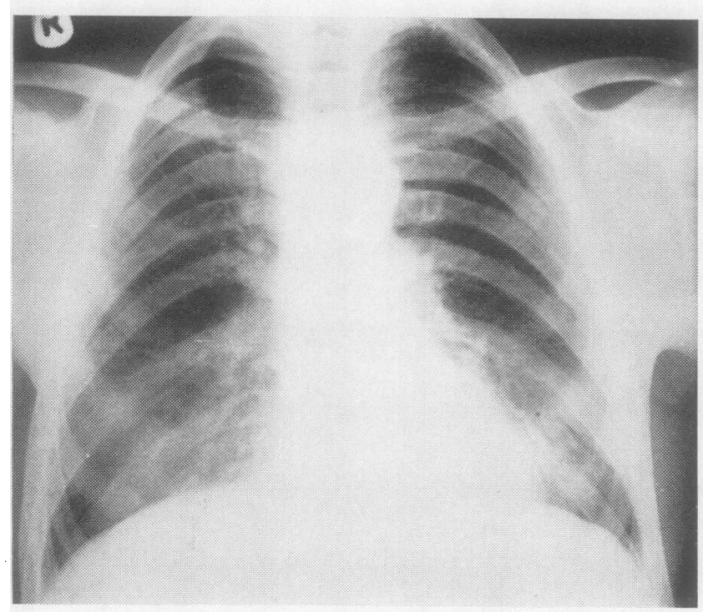

(b)

FIG. 3.-Functional changes (a) in a patient (Case 38) whose radiograph $(b)$ had been passed as normal. Exposure was for 22 years as a lagger. grade of dyspnoea, those with grade 5 dyspnoea have been excluded as there were only two patients (Cases 13 and 34) in this group and both these were complicated cases with functional evidence of emphysema.

The results are given in Table $\mathrm{V}$. It can be seen that there was highly significant correlation $\vec{\circ}$ between reduction in diffusing capacity and the severity of dyspnoea which is illustrated in Fig. 4. There was no correlation between grade of

\section{TABLE V}

RELATION BETWEEN DIFFERENT LUNG FUNCTION TESTS AND SEVERITY OF CLINICAL AND RADIOLOGICAL CHANGES

\begin{tabular}{|c|c|c|c|}
\hline \multicolumn{2}{|c|}{ Correlation Between: } & \multicolumn{2}{|c|}{ Correlation Coefficient ( $r$} \\
\hline 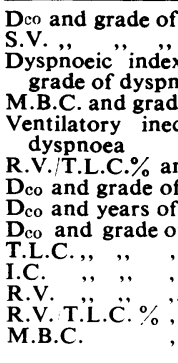 & 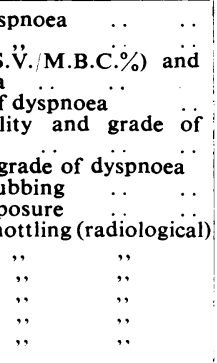 & $\begin{array}{l}-0.67 \\
+0.60 \\
+0.61 \\
-0.30 \\
-0.69 \\
-0.56 \\
-0.66 \\
+0.08 \\
-0.74 \\
-0.31 \\
-0.39 \\
-0.09 \\
-0.42 \\
-0.24\end{array}$ & $\begin{array}{l}p<0.001 \\
p<0.001 \\
p<0.001 \\
p>0.05 \\
p<0.001 \\
p<0.001 \\
p<0.001 \\
p>0.10 \\
p<0.001 \\
p \simeq 0.05 \\
p \simeq 0.02 \\
p>0.10 \\
p \simeq 0.01 \\
p>0.10\end{array}$ \\
\hline
\end{tabular}

dyspnoea and reduction in maximum breathing capacity. The standardized ventilation and dyspnoeic index, which is the ratio of standardized ventilation to the maximum ventilatory capacity, were also closely related to the grade of dyspnoea. It was of interest to find such a good correlation between reduction in diffusing capacity and the grade of finger clubbing (Fig. 5).

There was a highly significant correlation between reduction in diffusing capacity and radiological grade of mottling (Fig. 6). Reduction in inspiratory capacity and total lung capacity were also related to the severity of radiological $N$ change but at lower levels of significance. As with $\mathbb{\omega}^{-}$ dyspnoea, there was no correlation between changes in maximum breathing capacity and radiological grade.

\section{Discussion}

An "alveolar-capillary block" or diffusion defect appears to be a remarkably constant finding in established cases of asbestosis. There were only two patients in this series who appeared to 




Fio. 4
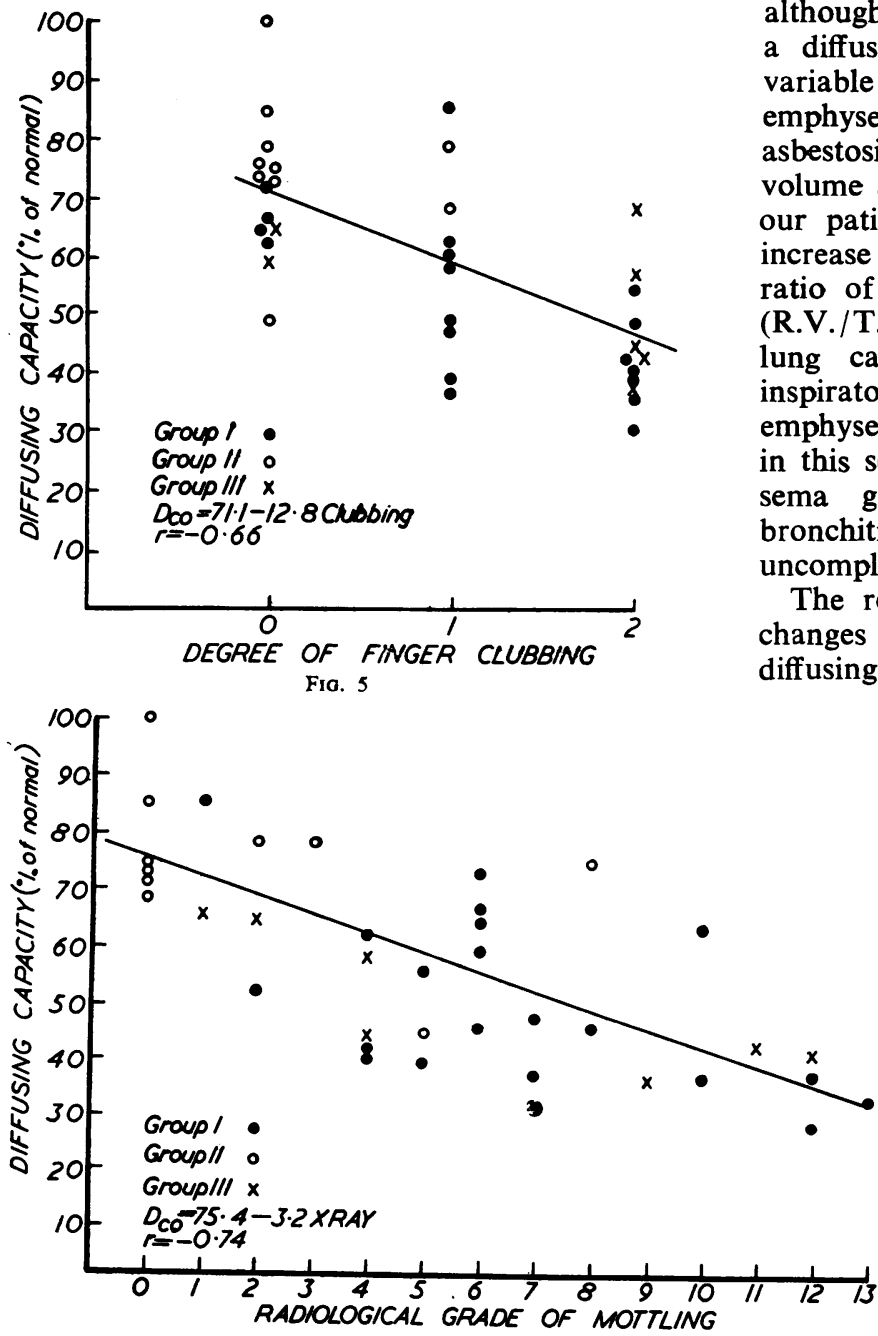

Fio. 6
FIG. 4. - The relation between diffusing capacity and grade of dyspnoea.

FIG. 5.-The relation between diffusing capacity and the severity of finger clubbing which was graded absent (0), slight (1), or marked (2).

FIG. 6.-The relation between diffusing capacity and grade of radiological mottling.

have a significant degree of complicating emphysema and these stood out in clear contrast to those with a pure diffusion defect. This is in contrast to the findings of Bastenier et al. (1955). They concluded that there was no specific physiopathological picture in pulmonary asbestosis, and although the fibrosis and vascular lesions caused a diffusion defect this was accompanied to a variable extent by the changes of secondary emphysema. In six of their eight cases of asbestosis there was an increase in residual volume and deficiency of pulmonary mixing. In our patients, with one exception, there was no increase in residual volume, and the rise in the ratio of residual volume to total lung capacity (R.V./T.L.C.\%) is simply due to the reduced total lung capacity consequent upon the lowered inspiratory capacity, and does not indicate emphysema. It is of interest that both the patients in this series with functional evidence of emphysema gave a history of recurrent purulent bronchitis which appeared to be rare in those with uncomplicated disease.

The results in our second group suggest that changes in pulmonary function, particularly the diffusing capacity, may precede clinical or radiological signs. Wright (1955) also found in his series cases showing well-marked functional changes in the absence of any clearly recognizable abnormality in the radiographs. He suggested that in these either the earliest radiological changes had been missed or the disease process was so diffuse in its early stages that there was poor contrast between normal and diseased areas and hence no definitely abnormal shadow on the radiograph. On the other hand, he also found patients in whom the disturbance of function was minimal despite the presence of definite $x$-ray changes, and in these he suggested that the disease process was focal in nature with large volumes 
of normal lung tissue remaining. In the present series there were no patients in whom the radiological appearances appeared to be out of proportion to the functional changes found, those with minimal radiological changes tending to have minimal functional changes also.

The finding of detectable changes in pulmonary function at an early stage in asbestosis is clearly of great importance, for it is at this stage that observer variation is so marked in the assessment of both physical signs and radiological appearances. The problem of observer variability in the radiological diagnosis of asbestosis has been discussed in detail elsewhere (Williams and HughJones, 1960). It is not only in early cases that disagreement occurs, and one of the most surprising findings in the study just referred to was the marked disagreement between the observers in reading the films from certified cases.

The presence of large bullae is not usually regarded as one of the characteristic radiological features of asbestosis, yet these were present in six of the present series (Cases 8 and 10 from Group 1, Case 24 from Group 2, and Cases 32, 33, and 34 in Group 3). The presence of these bullae did not appear to affect the functional changes. One patient had an increase in residual volume, but we have referred earlier to his functional evidence of emphysema.

The changes in the plasma protein fraction were of considerable interest, for similar changes had been observed in silicosis (Vigliani, Boselli, and Pecchiai, 1950) and have been part of the evidence put forward in favour of an immunological origin of the hyaline tissue of the silicotic nodule (Vigliani and Pernis, 1958). Possibly a similar mechanism is of importance in asbestosis. The exact cause of the fibrosis in this disease remains unknown. Knox and Beattie (1954) suggest that a fibrogenic agent is released from the breakdown of asbestosis bodies. They found that the severity of the lesion at necropsy was not related to the mineral content of the lung but was associated with a lengthening of the combined exposure and survival time, the survival time being the interval between the last exposure to dust and death. The mineral content of the lung tended to decline with increasing survival time. In the present series, however, there was no correlation during life between the changes in diffusing capacity and either the years of exposure or the total number of years between first exposure and time of study. Individual susceptibility to the disease is undoubtedly an important factor. Wright (1955b) noted that there were some patients with prolonged and intense exposure who failed to show any change in radiological or physiological tests. In the present series it was possible to compare individual $\bar{c}$ patients in the various groups, e.g., Cases 11 and 22 had both worked unloading crude asbestos for a comparable period of time (18 and 16 years respectively), yet one (Case 11) had definite clinical, क radiological, and functional signs of the disease whereas the other had a normal radiograph, no symptoms, and only minimal functional changes. $\vec{\omega}$

The severity of breathlessness in our patients was related to the degree of diffusion defect and $\vec{x}$ not to reduction in ventilatory capacity. If it is accepted that the sensation of dyspnoea can be $\tilde{N}$ related to the ratio between the air requirements for a given amount of exercise and the maximum $\odot$ possible ventilation or maximum breathing 음 capacity (Baldwin et al., 1948 ; Warring, 1949; Hugh-Jones, 1952), then it is clear that the $c$

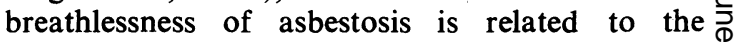
increased air requirement consequent on the $\vec{P}$ diffusion defect rather than to the reduction in ventilatory capacity. This is in contrast to the findings in coal-workers' pneumoconiosis, where there is little increase in the ventilatory requirement of exercise and the severity of breathlessness is closely related to the fall in maximum breathing capacity (Gilson and Hugh-Jones, 1955). $\stackrel{\varnothing}{\complement}$

Another factor besides hypoxia from the $\overrightarrow{\overrightarrow{0}}$ diffusion defect which may cause exercise hyper- $\frac{0}{3}$ ventilation in interstitial fibrosis may be excess $\supsetneq$ stimuli from stretch reflexes in the lungs resulting from the excessive lung "stiffness." Unfortunately it was only possible to measure the stiffness of the lung in one case where it was increased as seen by a reduced compliance.

The finding of a large ventilation-perfusion ratio inequality in many of the cases in this series was $\delta$ of considerable interest. This has been discussed 3 in more detail elsewhere (Read and Williams, 욱 1959) where the changes found in 28 patients with various interstitial diseases, including a number with asbestosis, are reported. Two patterns of disturbed function were described. That in which \% the ventilation-perfusion ratio inequality was 0 simply the result of ventilatory inequality, per- N fusion remaining normal, and that in which there was gross unevenness of perfusion in addition to

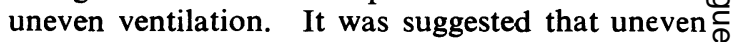
perfusion was due to superadded cysts or $\stackrel{0}{?}$ generalized emphysema, for the second pattern 0 was found only in those patients with a low $\overrightarrow{0}$ F.E.V.\% or radiological evidence of cyst $\stackrel{\AA}{\AA}$ formation.

The ventilatory inequality in apparently pure $\frac{\varrho}{\sigma}$ examples of interstitial disease, i.e., where there is no evidence of airway obstruction, may possiblyo 
be related to local abnormalities of expansion. Motley (1958) has recently suggested that ventilation-perfusion ratio imbalance is the cause of the arterial oxygen desaturation on exercise in interstitial diseases. It is worthy of note therefore that the three cases in the second group which showed desaturation on exercise had a ventilationperfusion ratio inequality within normal limits.

It is of course impossible to say that a man has asbestosis without pathological confirmation, but the other diseases which cause a similar functional lesion, such as scleroderma, some cases of sarcoidosis, the Hamman-Rich syndrome, lymphangitis carcinomatosa, are rare. The finding, therefore, of changes in diffusing capacity without any airflow obstruction in a patient with a history of exposure to asbestos is strong suggestive evidence of asbestosis whatever the radiological appearances.

\section{SUMMARY}

A study is described of the lung function in 40 patients who had been exposed to asbestos dust in their work for varying periods of time. These included 21 certified cases of asbestosis, 10 patients with a prolonged exposure but no definite radiological signs, and nine in whom the diagnosis of asbestosis was in doubt.

The functional changes of asbestosis were those common to other interstitial fibroses, and consisted of a lowered diffusing capacity together with a reduced inspiratory capacity, hyperventilation (often accompanied by arterial desaturation) on exertion with no evidence of airflow obstruction except in cases complicated by asthma or emphysema. Many patients also showed inequality of ventilation and ventilationperfusion ratio.

These functional changes were related to an independent grading of physical signs and radiological appearances Changes in lung function, specific for an interstitial fibrosis, often precede definite changes in the radiograph, so that their finding in patients with a history of exposure to asbestos is suggestive evidence of asbestosis whatever the radiological appearances.

We would like to thank the Cape Asbestos Co. Ltd. for their wholehearted co-operation, Dr. W. J. Smither, Works Medical Officer, without whose help much of this study would have been impossible, Dr. R. M. McGowan, of the London Pneumoconiosis Medical Panel, and Dr. J. C. McVittie, of the Ministry of National Insurance, who initially suggested the investigation. We are indebted to Dr. John Read for the mass spectrometer findings and Miss Heather MacLeish for valuable help, including the measurements of resting ventilation.

\section{REFERENCES}

Austrian, R., McClement, J. H., Renzetti, A. D., Donald, K. W. Riley, R. L., and Cournand, A. (1951). Amer. J. Med., 11, 667. Bader, M.E., Bader, R. A., and Selikoff, I. J. (1957). J. clin. Invest. 36,871 .

Baldwin, E. DeF., Cournand, A., and Richards, D. W., Jr. (1948) Medicine (Baltimore), 27, 243.

Bastenier, H., Denolin, H., Coster, A. de, and Englert, M. (1955). Arch. Mal, prof., 16, 546.

Bernstein, L., D'Silva, J. L., and Mendel, D. (1952). Thorax, 7, 255.

Doll, R. (1955). Brit. J. industr. Med., 12, 81.

Fletcher, C. M. (1952). Proc. roy. Soc. Med., 45, 577.

Gernez-Rieux, C., Balgairies, E., and Claeys, C. (1954). J. franc. Méd. Chir. thor. 8, 193 .

Med. Chir. thor., 8, 193.
Gilson, J. C., and Hugh-Jones, P. (1949). Clin. Sci., 7, 185.

Gilson, J. C., and Spec. Rep. Ser. med. Res. Coun. (Lond.), No. 290. Hugh-Jones, P. (1952). Brit. med. J., 1, 65.

Knox, J. F., and Beattie, J. (1954). A.M.A. Arch. industr. Hyg., $10,23$.

MacLeish. H. (1960). Personal communication.

Motley, H. L. (1958). Dis. Chest, 33, 581 .

Needham, C. D., Rogan, M. C., and McDonald, I. (1954). Thorax, 9,313 .

Ogilvie, C. M., Forster, R. E., Blakemore, W. S., and Morton, J. W. (1957). J. clin. Invest., 36, 1.

Read, J., and Williams, R. S. (1959). Amer. J. Med., $27,545$.

Roemheld, L., Kempf, H., and Wedler, H. W. (1940). Dtsch. Arch. klin. Med., 186, 53.

Vigliani, E., Boselli, A., and Pecchiai, L. (1950). Med. d. Lavoro, 41, 33.

and Pernis, B. (1958). Brit. J. industr. Med., 15, 8.

Warring, F. C. (1949). Amer. Rev. Tuberc., 60, 149.

West, J. B., Fowler, K. T., Hugh-Jones, P., and O'Donnell, T. V. (1957). Clin. Sci., 16, 529.

Williams, R., and Hugh-Jones, P. (1960). Thorax, 15, 103.

Wright, B. M. (1955a). J. Physiol. (Lond.), 127, 25P.

Wright, G. W. (1955b). A.M.A. Arch. industr. Hith,11, 196. 